\title{
Nitrate and bromate removal by autotrophic and heterotrophic denitrification processes: batch experiments
}

\author{
Sevgi Demirel ${ }^{1 *}$ and Ibrahim Bayhan ${ }^{2}$
}

\begin{abstract}
The effects of various parameters on bromate reduction were tested using lab-scale batch reactors with sulfur based autotrophic and methanol based heterotrophic denitrification processes. The initial bromate $\left(\mathrm{BrO}_{3}^{-}\right)$concentration of 100 and $500 \mu \mathrm{g} / \mathrm{L}$ was completely reduced and bromide (Br) was produced stoichiometrically from bromate in all batch reactors. In all experiments, nitrate was completely reduced to below detection limit. Kinetic studies showed that the sulfur-based autotrophic nitrate reduction rate increased with increasing initial nitrate concentration. At stoichiometrically sufficient methanol concentration as an external carbon source, nitrate and bromate were reduced to below US EPA drinking water limits in heterotrophic denitrification conditions. The methanol was completely depleted at the end of the heterotrophic operation conditions.
\end{abstract}

Keywords: Nitrate, Bromate, Autotrophic denitrification, Heterotrophic denitrification, Batch reactor

\section{Introduction}

Bromate is a disinfection by-product produced from bromide $\left(\mathrm{Br}^{-}\right)$contained in water when ozonation is applied in the drinking water [1]. Bromate is a suspected genotoxic carcinogen and has been shown that it causes renal tumors in rats and mice [2]. A maximum allowed contaminant level of bromate is $10 \mu \mathrm{g} / \mathrm{L}$ by United States Environmental Protection Agency (US EPA). Bromate cannot be removed by traditional water treatment methods such as filtration, chlorination or lime softening [3].

Nitrate has become a problem in many part of the world as well as in Turkey. The US EPA has set the maximum contaminant levels of $10 \mathrm{mg} \mathrm{NO}{ }_{\overline{3}} \mathrm{~N} \mathrm{~L}^{-1}$ (nitrate) for drinking water [4]. Reverse osmosis, electrodialysis and ion exchange are the physico-chemical methods used for treatment of nitrate from drinking waters $[5,6]$. The main disadvantages of these methods are high operation and maintenance cost, generation of secondary waste brines. As an alternative, biological

\footnotetext{
* Correspondence: sevgi.demirel@gmail.com

'Environmental Engineering Department, Nigde University, Nigde, Turkey

Full list of author information is available at the end of the article
}

denitrification, either autotrophic or heterotrophic has been proposed separately for nitrate and/or bromate removal $[7,8]$.

Sulfur-based autotrophic denitrification is an effective alternative due to low cost and availability of elemental sulfur [9]. It is insoluble and provides a slow release supply of electrons on demand, offering advantages of low maintenance.

In this process, the elemental sulfur acts as an electron donor, and nitrate serves as an electron acceptor. Hence, when nitrate is reduced to nitrogen gas, sulfur is oxidized to sulfate (reaction (1)).

$$
\begin{aligned}
& \mathrm{NO}_{3}+1.10 \mathrm{~S}^{0}+0.4 \mathrm{CO}_{2}+0.76 \mathrm{H}_{2} \mathrm{O} \\
& \quad+0.08 \mathrm{NH}_{4} \rightarrow 0.08 \mathrm{C}_{5} \mathrm{H}_{7} \mathrm{O}_{2} \mathrm{~N}+1.10 \mathrm{SO}_{4^{2-}} \\
& \quad+0.5 \mathrm{~N}_{2}+1.28 \mathrm{H}^{+}
\end{aligned}
$$

On the other hand, heterotrophic denitrifying bacteria need an organic carbon source for respiration and growth. A wide variety of organic carbon sources have been used such as methanol, ethanol, glucose, acetate etc. If methanol is used as a carbon source, the 
Table 1 Operational conditions in the sulfur-based batch reactors

\begin{tabular}{cccc}
\hline Batch Reactors & $\mathrm{BrO}_{\mathbf{3}}^{-}(\boldsymbol{\mu g} / \mathbf{L})$ & $\mathbf{N O}_{\mathbf{3}}-\mathbf{N}(\mathbf{m g} / \mathbf{L})$ & $\mathrm{K}_{\mathbf{2}} \mathrm{HPO}_{\mathbf{4}}$ \\
\hline R1 & 100 & 25 & 50 \\
R2 & 100 & 50 & 50 \\
R3 & 100 & 75 & 50 \\
R4 & 500 & 25 & 50 \\
R5 & 500 & 50 & 50 \\
R6 & 500 & 75 & 50 \\
\hline
\end{tabular}

stoichiometric relationships are written as follows (reaction (2)).

$$
\begin{aligned}
& \mathrm{NO}_{3-}+1.08 \mathrm{CH}_{3} \mathrm{OH} \\
& \quad+0.24 \mathrm{H}_{2} \mathrm{CO}_{3} \rightarrow 0.056 \mathrm{C}_{5} \mathrm{H}_{7} \mathrm{NO}_{2}+0.47 \mathrm{~N}_{2} \\
& \quad+1.68 \mathrm{H}_{2} \mathrm{O}+\mathrm{HCO}_{3}
\end{aligned}
$$

The aim of presented experiment was to evaluate the feasibility of the denitrification concept to the removal of a micropollutant such a bromate (in the $\mu \mathrm{g} / \mathrm{L}$ range) from contaminated water, containing nitrate at much higher concentration (in the $\mathrm{mg} / \mathrm{L}$ range) using batch reactors. The process has monitored for by products and performance of the autotrophic and heterotrophic denitrification processes was investigated in a series of experiments operated under different initial bromate, nitrate and methanol (as an organic carbon source) concentrations.

\section{Methods}

\section{Sulfur-based autotrophic batch experiments}

The sulfur-based autotrophic denitrification was tested in $150 \mathrm{~mL}$ serum bottles at $30^{\circ} \mathrm{C}$, filled with medium supplemented with $50 \mathrm{mg} / \mathrm{L} \mathrm{K}_{2} \mathrm{HPO}_{4}$. The batch reactors were consisted of $3 \mathrm{~g}$ sulfur and limestone particles. Batch experiments were carried out in three different nitrate concentrations $(25,50$ and $75 \mathrm{mg} / \mathrm{L})$ and two different bromate concentrations (100 and $500 \mu \mathrm{g} / \mathrm{L}$ ) (Table 1). Then, the serum bottles were inoculated with the $5 \mathrm{~mL}(130 \pm 18 \mathrm{mg} \mathrm{VSS} / \mathrm{L}$ medium) of denitrifying activated sludge which obtained from the first anoxic tank of a five stage
Bardenpho process located in Harran University Campus (Sanliurfa, Turkey).

\section{Methanol-based heterotrophic batch experiments}

Similar to autotrophic conditions, the heterotrophic denitrification was tested with same $\mathrm{K}_{2} \mathrm{HPO}_{4}, \mathrm{NO}_{3}{ }^{-}$, bromate and biomass concentrations (Table 2). In order to obtain heterotrophic denitrification conditions, methanol was added to the medium at two different concentrations. All the serum bottles were flushed with $\mathrm{N}_{2}$ gas to ensure anoxic conditions. All the serum bottles were sparged with $\mathrm{N}_{2}$ gas for 20 minutes to ensure the removal of dissolved oxygen as Sahinkaya \& Dursun [10] reported.

\section{Sampling and analytical techniques}

Samples for analysis were collected for the measurement of $\mathrm{BrO}_{3}^{-}, \mathrm{Br}^{-}, \mathrm{NO}_{3}^{-}, \mathrm{NO}_{2}^{-}$, dissolved organic carbon (DOC), sulfate, $\mathrm{pH}$, and alkalinity. All samples were filtered over a $0.45 \mu \mathrm{m}$-pore-size sterile filter. $\mathrm{NO}_{3}{ }^{-}, \mathrm{NO}_{2}{ }^{-}$and $\mathrm{SO}_{4}{ }^{2-}$ concentrations were determined by ion chromatography (Schimadzu, Prominence HICNS, IC-A3 column). $\mathrm{BrO}_{3}{ }^{-}$and $\mathrm{Br}^{-}$were measured by ion chromotography (DIONEX-ICS 3000 with AS19 column, bromate detection limit of $3 \mu \mathrm{g} / \mathrm{L}$ ). DOC was measured by TOC analyzer (TOC $\mathrm{V}_{\mathrm{CPH}}$, Shimadzu, Japan).

\section{Results and discussion}

Performance of autotrophic denitrification process

In order to examine denitrification performance with initial different nitrate and bromate concentrations,

Table 2 Operational conditions in the heterotrophic batch reactors

\begin{tabular}{cccc}
\hline Batch Reactors & $\mathrm{BrO}_{\mathbf{3}}^{-}(\boldsymbol{\mu g} / \mathrm{L})$ & $\mathbf{N O}_{\mathbf{3}}-\mathbf{N}(\mathbf{m g} / \mathbf{L})$ & $\mathbf{K}_{\mathbf{2}} \mathrm{HPO}_{\mathbf{4}}$ \\
\hline R1 & 100 & 45 & 50 \\
R2 & 500 & 45 & $50(19.7)$ \\
R3 & 100 & 45 & $50(19.7)$ \\
R4 & 500 & 45 & $115(45.3)$ \\
\hline
\end{tabular}

*Values in parenthesis shows the methanol concentrations as DOC. 
Table 3 Denitrification rates for sulfur-based autotrophic denitrification

\begin{tabular}{ccccc}
\hline $\mathrm{BrO}_{\mathbf{3}}^{-}(\boldsymbol{\mu g} / \mathbf{L})$ & $\mathbf{N O}_{\mathbf{3}}-\mathbf{N}(\mathbf{m g} / \mathbf{L})$ & Denitrification rates $\left(\mathbf{m g ~ N O}_{\mathbf{3}}-\mathbf{N} / \mathbf{L}\right.$. day) & $\begin{array}{c}\text { Maximum Nitrit Accumulation } \\
\left(\mathbf{m g ~ N O}_{\mathbf{2}}-\mathbf{N} / \mathbf{L}\right)\end{array}$ & $\begin{array}{c}\mathrm{SO}_{\mathbf{4}}^{-} \text {Production } \\
(\mathbf{m g} / \mathbf{L})\end{array}$ \\
\hline 100 & 25 & 5.26 & $4.7 \pm 0.9$ & 412 \\
& 50 & 8.69 & $1.4 \pm 2.3$ & 649 \\
& 75 & 11.26 & $7.3 \pm 3.5$ & 712 \\
500 & 25 & 4.63 & $2.3 \pm 1.1$ & 372 \\
& 50 & 8.27 & $4.9 \pm 2.1$ & 458 \\
& 75 & 9.67 & $5.0 \pm 2.3$ & 749 \\
\hline
\end{tabular}

6 batch tests were performed under autotrophic conditions. In these batch experiments, the elemental sulfur acts as an electron donor and nitrate serves as an electron acceptor (reaction (1)). Hence, when nitrate is reduced to nitrogen gas, sulfur is oxidized to sulfate (reaction (1)).
The batch reactors were operated under autotrophic conditions at two concentrations of bromate (100 and $500 \mu \mathrm{g} / \mathrm{L})$ and three concentrations of nitrate $(25,50$ and $75 \mathrm{mg} / \mathrm{L}$ ). It was observed that nitrate concentration decreased after inoculation of denitrifiers to the batch reactors. Nitrite was detected as an intermediate and
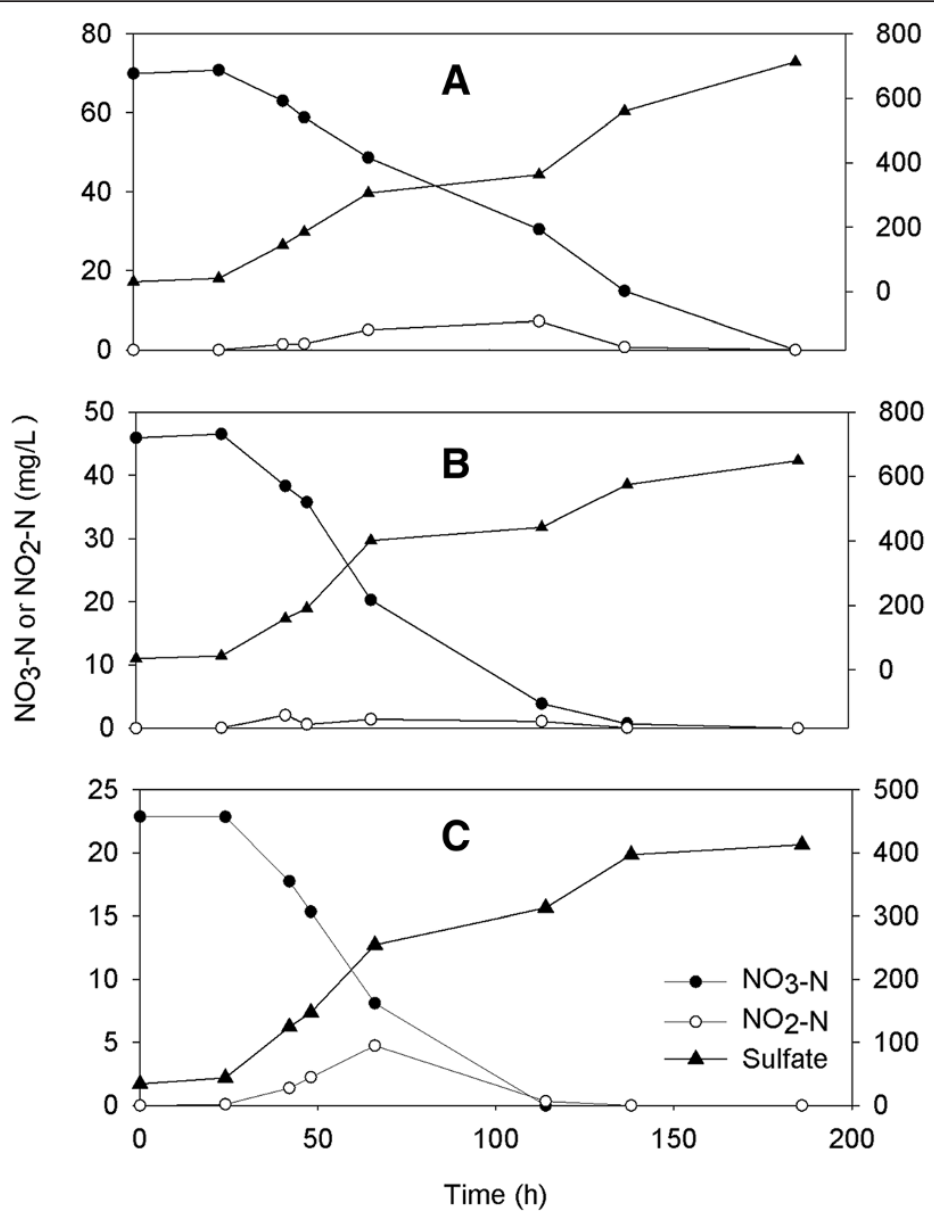

Figure 1 The variations of $\mathrm{NO}_{3}^{-}-\mathrm{N}, \mathrm{NO}_{2}^{-}-\mathrm{N}$ and sulfate concentrations in batch experiments at different initial $\mathrm{NO}_{3}^{-}-\mathrm{N}$ concentrations $\left[100 \mu \mathrm{g} / \mathrm{L} \mathrm{BrO}_{3}^{-}{ }^{-}\right.$. (A) $75 \mathrm{mg} / \mathrm{L} \mathrm{NO}_{3}{ }^{-} \mathrm{N}^{-}$(B) $50 \mathrm{mg} / \mathrm{L} \mathrm{NO}_{3}{ }^{-} \mathrm{N}$; (C) $25 \mathrm{mg} / \mathrm{L} \mathrm{NO}_{3}{ }^{-} \mathrm{N}$. 

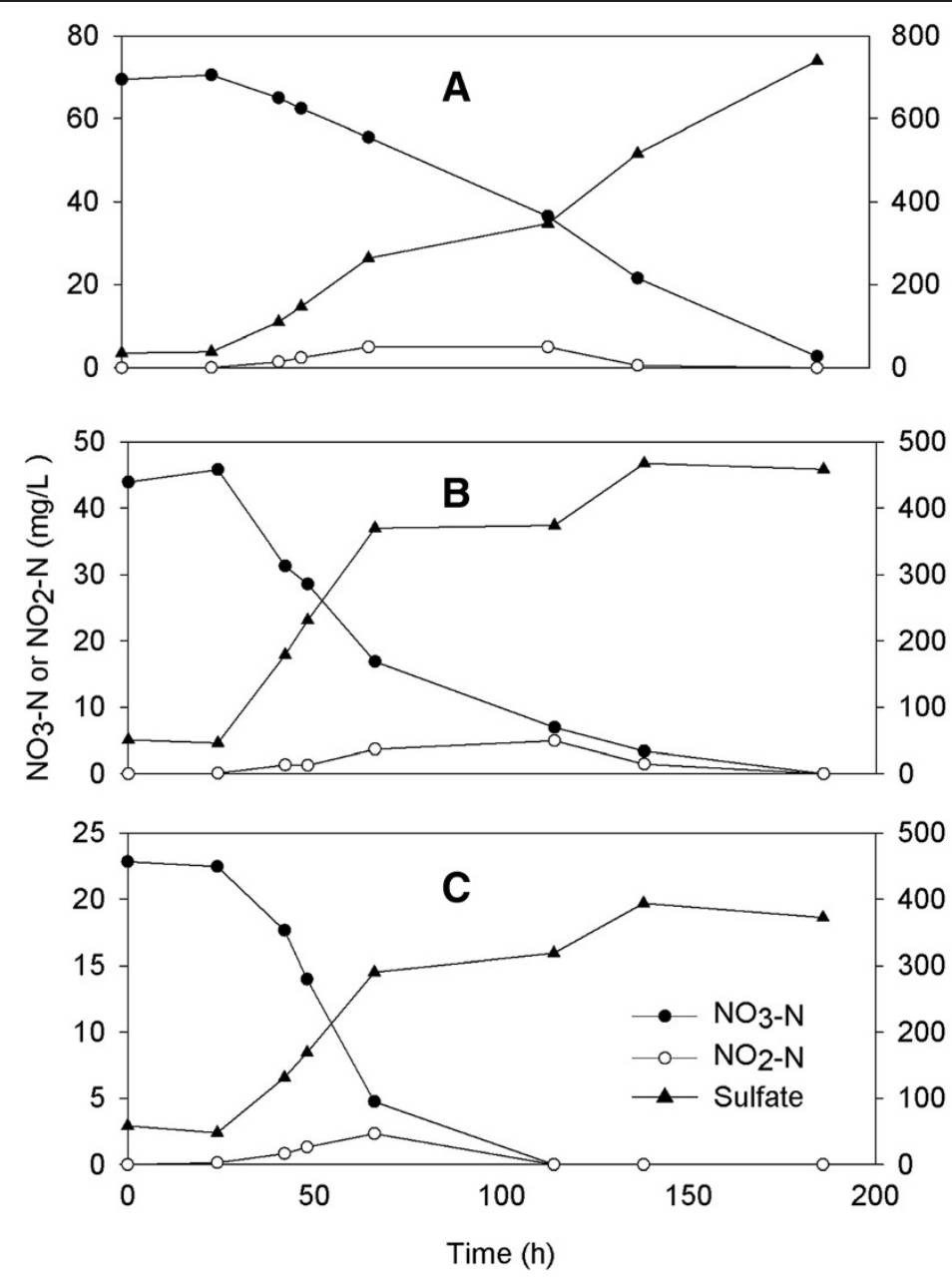

Figure 2 The variations of $\mathrm{NO}_{3}^{-}-\mathrm{N}, \mathrm{NO}_{2}^{-}-\mathrm{N}$ and sulfate concentrations in batch experiments at different initial $\mathrm{NO}_{3}^{-}-\mathrm{N}^{-}$concentrations $\left[500 \mu \mathrm{g} / \mathrm{L} \mathrm{BrO}_{3}^{-}{ }^{-}\right.$. (A) $75 \mathrm{mg} / \mathrm{L} \mathrm{NO}_{3}{ }^{-} \mathrm{N}$; (B) $50 \mathrm{mg} / \mathrm{L} \mathrm{NO}_{3}{ }^{-} \mathrm{N}$; (C) $25 \mathrm{mg} / \mathrm{L} \mathrm{NO}_{3}{ }^{-} \mathrm{N}^{-}$.

maximum $\mathrm{NO}_{2}{ }^{-} \mathrm{N}$ concentration was reached $7.3 \pm$ $3.5 \mathrm{mg} / \mathrm{L}$ during bromate and nitrate removal. $\mathrm{NO}_{2}{ }^{-} \mathrm{N}$ was decreased rapidly after $100 \mathrm{hrs}$ which indicates that denitrification occurred within the system (Figure 1).

The reduction rates of $\mathrm{NO}_{3}{ }^{-}-\mathrm{N}$ at various initial $\mathrm{NO}_{3}{ }^{-} \mathrm{N}$ and $\mathrm{BrO}_{3}^{-}$concentrations were studied in batch serum bottles. The results of batch assays were summarized at Table 3. The theoretical sulfate productions calculated according to reaction (1) assuming complete denitrification were 189, 377 and $578 \mathrm{mg} / \mathrm{L}$ for 25,50 and $75 \mathrm{mg} / \mathrm{L}$ nitrate respectively. The measured sulfate production was higher than the theoretically calculated values, which should be due to the input of oxygen during sampling.

Although sulfur-based autotrophic denitrification has several advantages, its main disadvantages are sulfate and acid formation. It is found that sulfate formation was increased as a result of sulfur oxidizing autotrophic denitrification during the experiment (Table 3 and Figures 1 and 2). The concentration of sulfate in autotrophic batch reactor was higher than sulfate limit value of $250 \mathrm{mg} / \mathrm{L}$, set by US EPA.

Figure 2 shows nitrate depletion and sulfate production with time using $500 \mu \mathrm{g} / \mathrm{L}$ bromate and nitrate at three different dosages $\left(25,50\right.$ and $\left.75 \mathrm{mg} / \mathrm{L} \mathrm{NO}_{3}{ }^{-} \mathrm{N}\right)$. The measured maximum $\mathrm{NO}_{2}{ }^{-}-\mathrm{N}$ concentrations were $2.3 \pm 1.1, \quad 4.9 \pm 2.1$ and $5.0 \pm 2.3 \mathrm{mg} / \mathrm{L}$, respectively (Table 3). Also, produced sulfate concentrations were determined 372, 458 and $749 \mathrm{mg} / \mathrm{L}$ in batch reactors for nitrate concentrations of 25,50 and $75 \mathrm{mg} / \mathrm{L}$ respectively. In this study, nitrate reduction rate increased with increasing initial nitrate concentration with transient nitrite accumulation. Similar finding was also reported by Hijnen et al. [11].

The nitrite accumulation was only transient and complete nitrate denitrification and bromate removal 

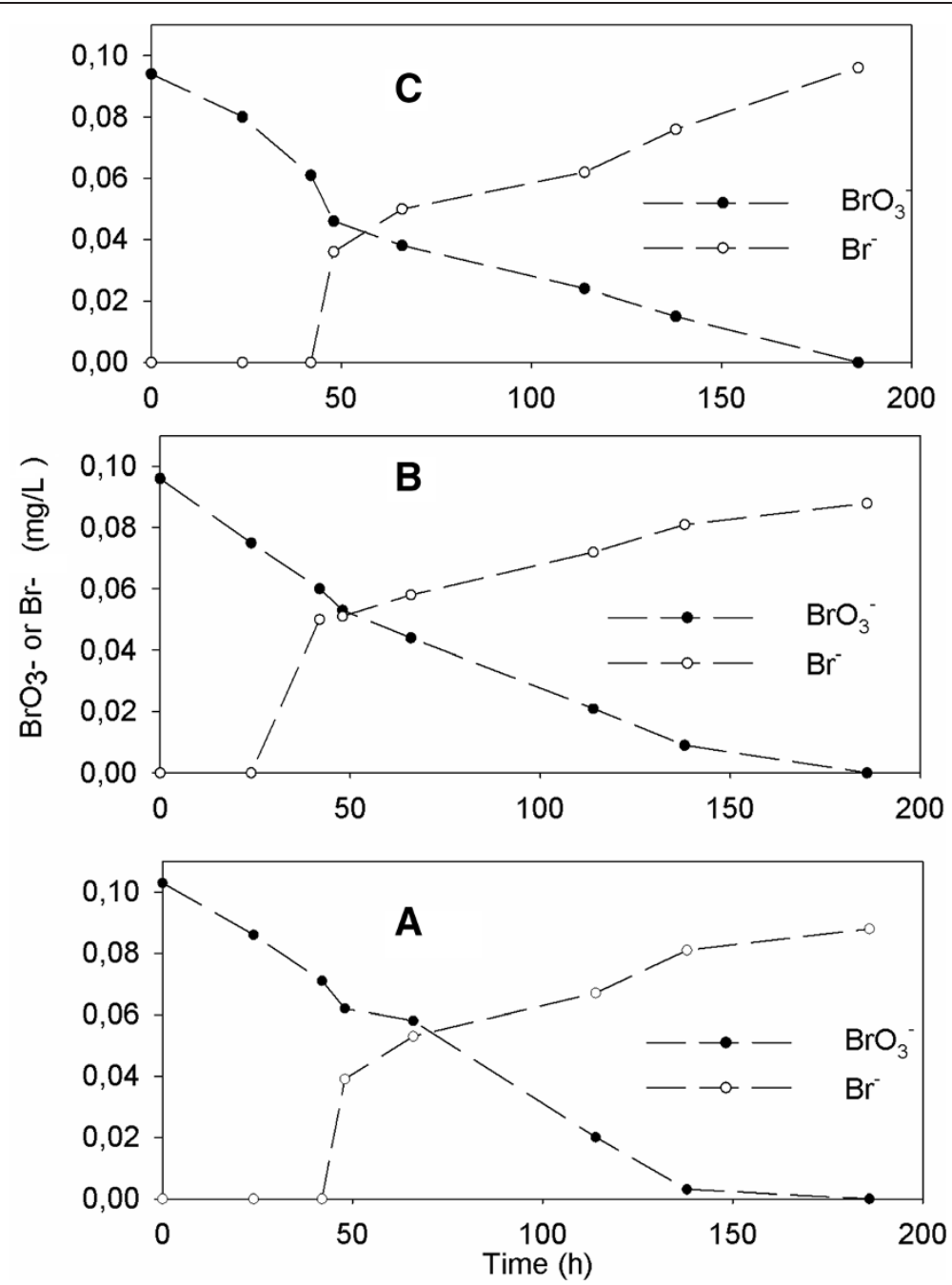

Figure 3 The variations of $\mathrm{BrO}_{3}^{-}$in batch experiments at different initial $\mathrm{NO}_{3}^{-}-\mathrm{N}$ concentrations $\left[100 \mu \mathrm{gg} / \mathrm{L} \mathrm{BrO}{ }^{-}\right]$. (A) $25 \mathrm{mg} / \mathrm{L} \mathrm{NO}{ }^{-}-\mathrm{N} ;(\mathrm{B})$ $50 \mathrm{mg} / \mathrm{L} \mathrm{NO}_{3}^{-}-\mathrm{N} ;$ (C): $75 \mathrm{mg} / \mathrm{L} \mathrm{NO}_{3}^{-}-\mathrm{N}$.

was observed at autotrophic batch experiment. The results of study showed that the bromate removal via autotrophic denitrification process was not effected increasing initial bromate concentrations from 100 to $500 \mu \mathrm{g} / \mathrm{L}$. Throughout the experiment, decreasing bromate simultaneously with a stoichiometric increase in bromide was observed at the steady state conditions (Figures 3 and 4).

Similar to this study, Krisits et al. [8] reported that nitrate reduction rate was faster than bromate. Matos et al. [12] noted that bromate reduction is thermodynamically less favorable (it releases less energy) compared to nitrate. Additionally, they observed that increasing initial bromate concentration (from $200 \mu \mathrm{g} / \mathrm{L}$ to $20.48 \mathrm{mg} / \mathrm{L}$ ) inhibit biological denitrification. The results showed that denitrification rate was relatively lower when increased initial bromate concentration in this study (Table 3). However, complete nitrate and bromate reduction were occurred at the end of the experiments.

\section{Performance of heterotrophic denitrification process}

Heterotrophic denitrifying bacteria use organic compounds as carbon and energy source. The organic compounds are required for complete denitrification depends on the nitrate concentration and bacteria yield coefficient. The nitrite accumulates in water when added organic is stoichiometrically insufficient $[6,13]$. On the other hand, the residual organic compound remains in the treated water when the added organic is excessive [13].

The C:N ratio is an important factor effecting the performance of heterotrophic denitrification process [14]. 


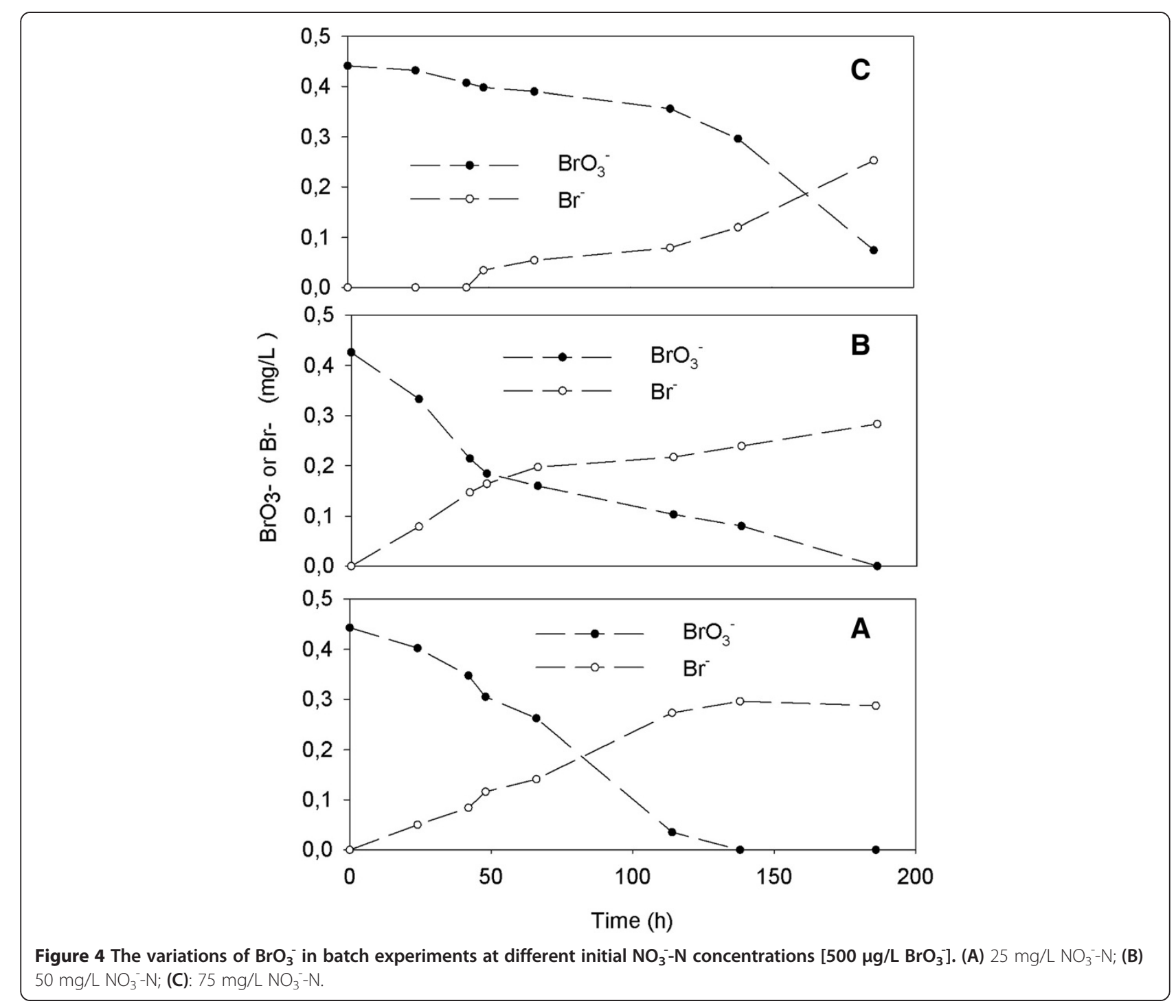

Liu et al. [15] reported that stoichiometrically C:N (mg $\mathrm{CH}_{3} \mathrm{OH}: \mathrm{NO}_{3}{ }^{-}-\mathrm{N}$ ) ratio was 2.47 for complete denitrification. In this study, $50 \mathrm{mg} / \mathrm{L}$ methanol $\left(\mathrm{mg} \mathrm{CH} \mathrm{CH}_{3} \mathrm{OH}\right.$ : $\mathrm{NO}_{3}{ }^{-} \mathrm{N}=1.11<2.47$ ) was added to the $\mathrm{R} 1$ and $\mathrm{R} 2$ (Table 2). This amount of methanol was lower than the stoichiometric ratio of 2.47 for complete heterotrophic denitrification (Figure 5).

In the presence of $50 \mathrm{mg} / \mathrm{L}$ methanol, the nitrite accumulation was observed due to insufficient organic carbon (Figure 5).

$115 \mathrm{mg} / \mathrm{L}$ methanol was added to the R3 and R4 to achieve complete denitrification process. Therefore, the denitrification rate increased with increasing feed methanol concentration as expected (Figure 6). The results with both nitrate and bromate suggest that denitrifying bacteria may be reducing bromate cometabolically.
The main disadvantage of the heterotrophic denitrification is needed external carbon resulting in secondary pollution [16]. On the basis of experimental results, the dissolved organic carbon (methanol) was almost completely removed in batch reactors which mean there was no observation of secondary pollution as illustrated in Figure 7. It was favorable for bromate and nitrate removal, especially drinking water treatment.

The exact bromate reduction mechanism by mixed denitrifying population is not known. It seems that bromate is cometabolically reduced by denitrifiers in the presense of nitrate.

\section{Conclusions}

Experiments showed that the denitrification rate was increased with increasing initial $\mathrm{NO}_{3}{ }^{-}-\mathrm{N}$ concentration. As 

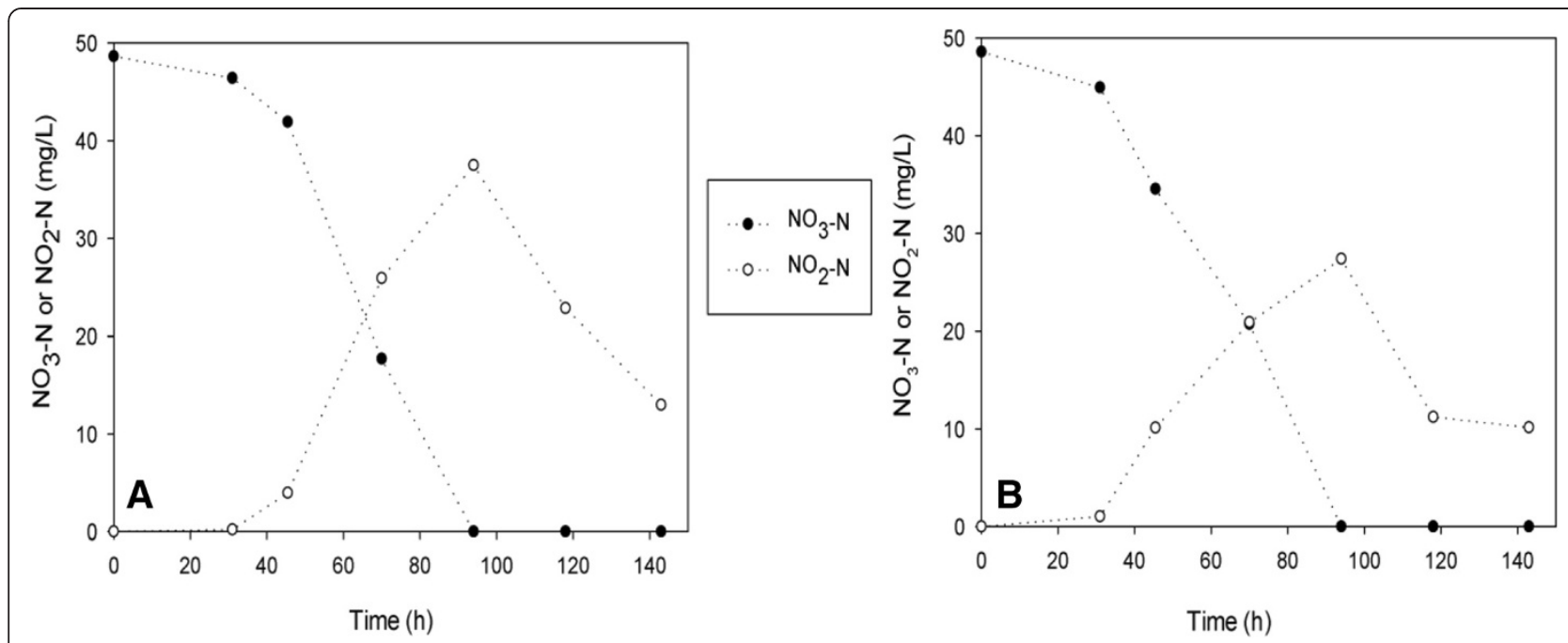

Figure 5 The variations of $\mathrm{NO}_{3}^{-}-\mathrm{N}$ and $\mathrm{NO}_{2}^{-}-\mathrm{N}$ in heterotrophic batch experiments at different initial $\mathrm{BrO}_{3}^{-}$concentrations $[19,7 \mathrm{mg} / \mathrm{L}$ methanol]. (A) $100 \mu \mathrm{g} / \mathrm{L} \mathrm{BrO}_{3}^{-}$(B) $500 \mu \mathrm{g} / \mathrm{L} \mathrm{BrO}_{3}^{-}$.

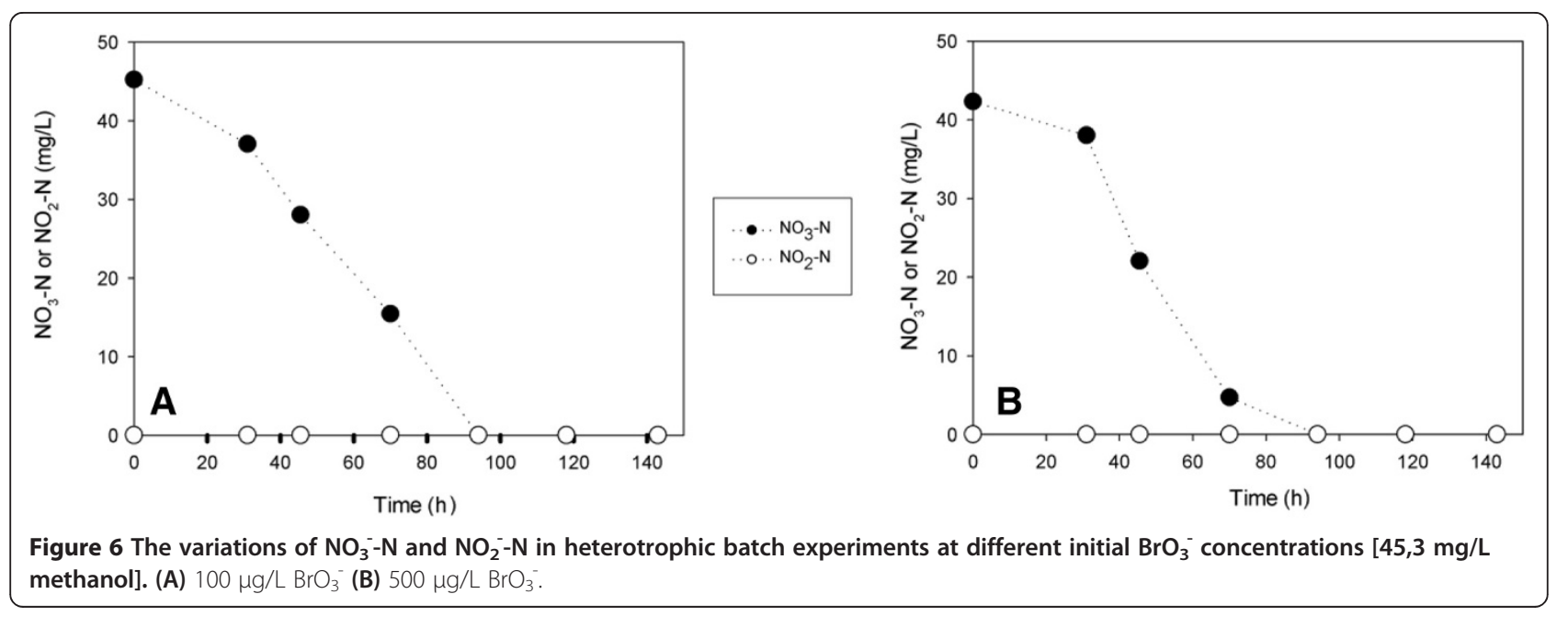

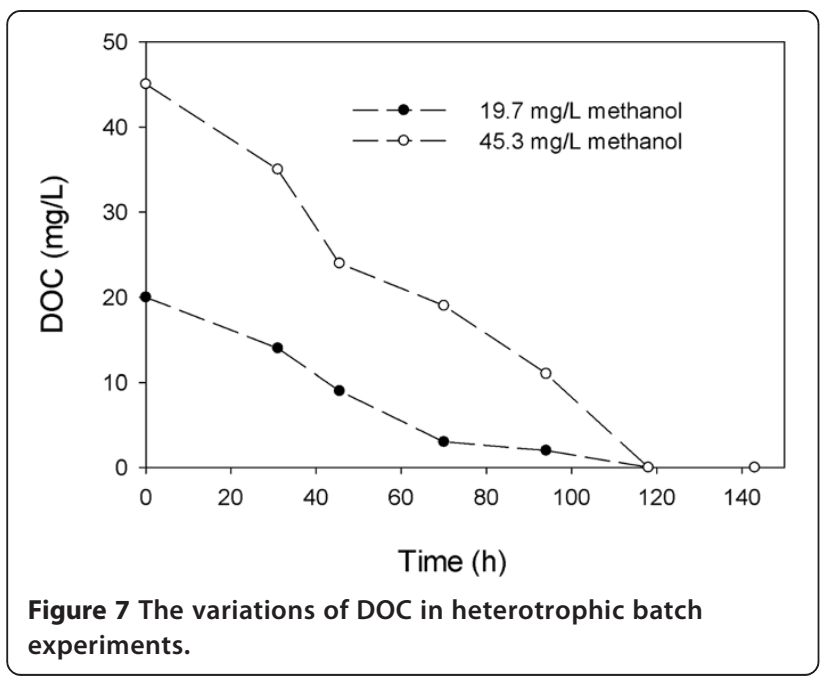

a result of sulfur-based autotrophic denitrification, effluent $\mathrm{SO}_{4}{ }^{2-}$ concentration increased at the end of the process. Effluent bromide measurements indicated that bromate was completely reduced without accumulation of by-products. Additionally, the effect of methanol concentration on bromate reduction by heterotrophic denitrification process was investigated. Batch studies show that $\mathrm{NO}_{2}{ }^{-}-\mathrm{N}$ accumulation was observed when methanol was added at methanol/ $\mathrm{NO}_{3}{ }^{-} \mathrm{N}$ ratio which was lower than the stoichiometric value $\left(\mathrm{mg} \mathrm{CH}_{3} \mathrm{OH}\right.$ : $\mathrm{NO}_{3}{ }^{-} \mathrm{N}=1.11<2.47$ ). This study showed that denitrification process was much faster and nitrite accumulation was not observed when adequate methanol was added. This study can be a contribution for the development of a biological process to remove the bromate and nitrate pollution from drinking water. 


\section{Competing interests}

The authors declare that they have no competing interests.

\section{Authors' contributions}

Corresponding author (SD) carried out design of the study, performed the batch experiments and drafted the manuscript. IB participated in batch reactor design. All authors read and approved the final manuscript.

\section{Acknowledgements}

This research was funded by The Scientific and Technological Research Council of Turkey (TUBITAK Project No: 111Y165).

\section{Author details}

${ }^{1}$ Environmental Engineering Department, Nigde University, Nigde, Turkey.

${ }^{2}$ Environmental Health Branch, Sanliurfa Provincial Directorate of Health,

Sanliurfa, Turkey.

Received: 13 May 2013 Accepted: 23 September 2013

Published: 19 December 2013

\section{References}

1. Gunten UV, Pinkernell U: Ozonation of bromide-containing drinking waters:a delicate balance between disinfection and bromate formation. Water Sci Technol 2000, 41(7):53-59.

2. Assunçao A, Martins M, Silva G, Lucas H, Coelho MR, Costa MC: Bromate removal by anaerobic Bacterial community: mechanism and phylogenetic characterization. J Haz Mat 2011, 197:237-243.

3. Butler R, Godley A, Lytton L, Cartmell E: Bromate environmental contamination: review of impact and possible treatment. Crit Rev Environ Sci Technol 2005, 35:193-217.

4. Yesilnacar Ml, Sahinkaya E, Naz M, Ozkaya B: Neural network prediction of nitrate in groundwater of Harran Plain, Turkey. Environ Geol 2008, 56:19-25.

5. Rocca CD, Belgiorno V, Meriç S: Overview of in-situ applicable nitrate removal processes. Desalination 2007, 204:46-62.

6. Sierra-Alvarez R, Beristan-Cordosa R, Salazar M, Gomez J, Razo-Flores E, Field JA: Chemolithotrophic denitrification with elemental sulfur for groundwater treatment. Water Res 2007, 41:1253-1262.

7. Hijnen WAM, Jong R, Kooij VD: Bromate removal in a denitrifying bioreactor used in water treatment. Water Res 1999, 33(4):1049-1053.

8. Kirisits M, Snoeyink V, Kruithof J: The reduction of bromate by granular activated carbon. Water Res 2000, 34(17):4250-4260.

9. Sahinkaya E, Dursun N, Kilic A, Demirel S, Uyanik S, Cinar O: Simultaneous heterotrophic and sulfur-oxidizing autotrophic denitrification process for drinking water treatment: control of sulfate production. Water Res 2011, 45:6661-6667.

10. Sahinkaya E, Dursun N: Sulfur-oxidizing autotrophic and mixotrophic denitrification processes for drinking water treatment: Elimination of excess sulfate production and alkalinity requirement. Chemosphere 2012, 89:144-149.

11. Hijnen WAM, Voogt R, Veenendaal H, Jaght VD, Kooij VD: Bromate reduction by denitrifyng bacteria. Appl and Environ Microbiol 1995, 61(1):239-244.

12. Matos CT, Velizarov S, Reis MAM, Crespo JG: Removal of bromate from drinking water using ion exchange membrane bioreactor concept. Environ Sci Technol 2008, 42:7702-7708.

13. Rijn VJ, Tal Y, Schreier HJ: Denitrification in recirculating systems: theory and applications. Aquacultural Engineering 2006, 34:364-376.

14. Guven D: Effects of different carbon sources on denitrification efficiency associated with culture adaptation and $\mathrm{C} / \mathrm{N}$ ratio. Clean - Soil Air Water 2009, 37(7):565-573.

15. Liu H, Jiang W, Wan D, Qu J: Study of a combined heterotrophic and sulfur autotrophic denitrification technology for removal of nitrate in water. J Haz Mat 2009, 169:23-28.

16. Zhao Y, Feng C, Wang Q, Yang Y, Zhang Z, Sugiura N: Nitrate removal from groundwater by cooperating heterotrophic with autotrophic denitrification in a biofilm-electrode reactor. J Haz Mat 2011, 192:1033-1039.

doi:10.1186/2052-336X-11-27

Cite this article as: Demirel and Bayhan: Nitrate and bromate removal by autotrophic and heterotrophic denitrification processes: batch experiments. Journal of Environmental Health Sciences \& Engineering 2013 11:27.

\section{Submit your next manuscript to BioMed Central and take full advantage of:}

- Convenient online submission

- Thorough peer review

- No space constraints or color figure charges

- Immediate publication on acceptance

- Inclusion in PubMed, CAS, Scopus and Google Scholar

- Research which is freely available for redistribution 